\title{
PROFESSOR RÜTER, THE DIRECTOR OF THE INSTITUTE
}

It is such a simple statement in the Annual Report for 1950 of the Internationaal Instituut voor Sociale Geschiedenis:

"In connection with the retirement of Professor Posthumus at the end of 1952 it was thought advisable to look for a successor in good time, in order to give him the opportunity of getting thoroughly acquainted with the work of the Institute. The Board is happy to announce that Professor Rüter, who was a collaborator of the Institute from its foundation till the war, is willing to be co-director. Till the end of $1952 \mathrm{Mr}$. Posthumus and Mr. Rüter will share the directorate. They will divide the work between them in a way still to be decided."

Now that, unfortunately much too soon, death has put an end to Professor Rüter's work and the period of his directorate of the Institute can be considered as a whole, it is clear that the confidence that was expressed by the words "The Board is happy to announce..." has proved fully justified.

After sharing the responsibility with Professor Posthumus for two years, Professor Rüter was the sole director of the Institute from 1953 till 1965 . This period has been a very important one for the development of the Institute.

Before the war the Institute was financed completely by De Centrale Arbeiders-Verzekeringsbank (Central Labourers Insurance Company). In those years a start was made by collecting material on a large scale. Under the direction of Professor Posthumus and his collaborators, one of whom was Rüter, archives, leaflets, books and periodicals were bought or otherwise acquired. The quantity, the nature and the special significance of the material acquired at that time have determined the unique place of the Institute as a centre for the study of social history.

The budget for 1939, published in the Annual Report for 1938, states the total expenditure at over $f$. 96,000 (about $£ 8,000$ ).

During the war the Institute was sacked by the occupying forces. After the war it cost a great deal of trouble to recollect the material that was scattered all over Europe. Fortunately, some important 
collections - such as the Marx-Engels archive - had been taken to a place of safety, so that the work of reconstruction could be started at once, be it in primitive circumstances. Financially, the situation of the Institute was much more difficult than before the war. De Centrale Arbeiders-Verzekeringsbank too had been taken "control" of by the occupying forces. What kind of control this was became very clear after the war, when the first calculation showed that the total amount of the loss was about $\mathrm{fl}$. 3,500,000.*

Fortunately, however, the City of Amsterdam and the Dutch Government saw the importance of the preservation and further development of the Institute and were prepared to share in the financial responsibility. When Professor Rüter became co-director with Professor Posthumus, an arrangement had already been made that De Centrale Arbeiders-Verzekeringsbank, the Government and the City of Amsterdam each carried one third of the cost, while the City also provided the building. Nevertheless, the situation is probably characterized most clearly by the fact that, although costs had risen after the war, the budgets of the Institute for the years 1950-1952 showed an amount of fl. 60,000 annually as the contribution of the three participants together.

This was the situation as Professor Rüter found it when he took up the directorate. The Institute was extremely important, considering its material, but its opportunities for development were exceedingly poor. It is during the period of Professor Rüter and largely owing to his initiative and leadership that this "exceedingly poor" gradually changed. To begin with, Professor Rüter induced the three participants to raise their contributions, so that these were about fl. 90,000 each in 1962. But he was also very active in obtaining subsidies from other organisations for ever changing special purposes, given thanks to the existing confidence in the work of the Institute. Many Annual Reports mention subsidies from the Netherlands Organisation for the Advancement of Pure Research, from the Deutsche Forschungsgemeinschaft, from the Rockefeller Foundation. It was Professor Rüter who made the contacts, who set out with concrete proposals for publications and research projects.

Yet, Professor Rüter judged, rightly, that the financial basis of the Institute was still too narrow to give it the position of international importance in the field of social history to which it was entitled. And when it became apparent that the ideas of the Government and the City of Amsterdam about the methods and the extent of university teaching and research were changing; when plans were suggested to

* After the war, I Dutch guilder was roughly equivalent to 2 sh. or $\$ 0.25$. 
establish inter-university institutes of a new type, Professor Rüter was on the spot and at once began negotiations with the Government and the City to make the Institute into such an inter-university institute. Thus, the financial basis would be sounder and the position of those employed by the Institute would be improved. For no one has fought harder to better the position of his staff, because he judged - again rightly - that, at least financially, they were undervalued in consequence of the limitations of the financial situation. Professor Rüter did live to see the plans for a transition to the status of interuniversity institute take a more concrete shape. He did not live to see it become a fact. But in the meantime he had found a way which, financially, led to the same result. Awaiting further decisions about the new organisation, the University of Amsterdam proved willing to take the Institute under its wings financially. The Government and the City of Amsterdam withdrew as participants. De Centrale Arbeiders-Verzekeringsbank continued to give subsidies, with the special aim of enabling the Institute to acquire important archives. The last budget drawn up by Professor Rüter - the one for 1966 - shows a subsidy of $\mathrm{fl} .76_{3}, 380$ from the University of Amsterdam and of fl. 60,000 from De Centrale Arbeiders-Verzekeringsbank.

The development described above was to a very large extent the result of Professor Rüter's exertion.

Still, this is only one aspect of his activity. From the beginning Professor Rüter clearly saw the other necessary tasks. Collecting material is one side of the work of the Institute and it is essential for its growth. But this material must be made accessible, it must be catalogued to render studies and publications possible. Before the war cataloguing had been started, but all that had been accomplished disappeared during the war. Making a complete catalogue and keeping it up-to-date went far beyond the financial means of the Institute in the first few years after the war. The way in which Professor Rüter tackled this problem was another proof of his exceptional qualities. He had an estimate made of the number of people who could be employed at cataloguing simultaneously and of the time the work would take, and thus came to an assessment of the cost that would have daunted nearly everybody into disbelief of ever obtaining the amount needed. But Professor Rüter had seen right: his contacts with the Ford Foundation had led him to believe that this foundation would rather grant a large subsidy for one extensive and important project than see the dispersion in the importance of the work done, resulting from granting small amounts for widely varied activities. Thanks to the way in which Professor Rüter stressed the importance 
of "his" project an amount of fl. I,300,000 was given and with this amount by far the greater part of the material of the Institute was catalogued.

The importance of this cataloguing has greatly increased as the veterans among the collaborators of the Institute, of whom Professor Rüter himself was one, are falling away. With them the Institute looses much knowledge about the documents and archives and their value, about what is there and what is not.

The availability and accessibility of the material are prerequisites for scientific research and the publication of sources and studies. It was with great perseverance that Professor Rüter strove to attain such publications and his effort was crowned with success. A considerable number of very important books appeared during his directorate; for a still greater number preparations were begun under his direction. Before the appearance of a book much work has to be done. One must know if the man who is to write the book and make the annotations for a publication of sources has the stature and perseverance needed to complete an often laborious task, once it has been begun. During the preparation or after the manuscript has been finished, an independent scholar must give his opinion and spot possible inaccuracies or shortcomings. Then there is the difficult job of negotiating about the publication of the work. For most publications have to be financed outside the normal budget of the Institute, that is to say from special funds or by finding a publisher willing to take upon him the not inconsiderable risk of publishing a limited edition of a usually expensive book. From quite close I have been able to observe how much Professor Rüter did in this field too, and to see how, by putting himself fully behind a work, he was able to convince others of the value of their co-operation in its publication.

It must be remembered that all these activities were not supposed to require a full day's work, since Professor Rüter also had his duty as a professor at the University of Leiden. Moreover, this is not an exhaustive description of every detail in the running of the Institute that required thought and action. Directing the scientific collaborators and the other members of the staff, selecting new staff in a tight labourmarket, establishing and maintaining many international contacts and making journeys that were necessary for the Institute, all these things had to be done as well in the time available. In addition, the great problem of the premises of the Institute required constant thought, and this became more urgent as the years passed. Professor Rüter has not lived to see a decision made about the erection of a new building. But I am convinced that, if he had been given the time, this decision 
would also have been reached thanks to his activity. All the preparative work had been done.

Laying the financial foundation on which the Institute can build its work in the future, bringing about the cataloguing of its collections, launching an extensive series of publications and by this means demonstrating the unique value of the Internationaal Instituut voor Sociale Geschiedenis for historical research, these are all achievements that mark the importance of Professor Rüter as an organizer.

For himself Professor Rüter always remained extremely modest, for the Institute he worked with unbending perseverance. With his great ability and his great authority, respected by everybody, he served the Institute in a way that goes far beyond what can be required or expected from one man. 